\title{
A cultura como performance Desenvolver um conceito
}

\section{Erika Fischer-Lichte}

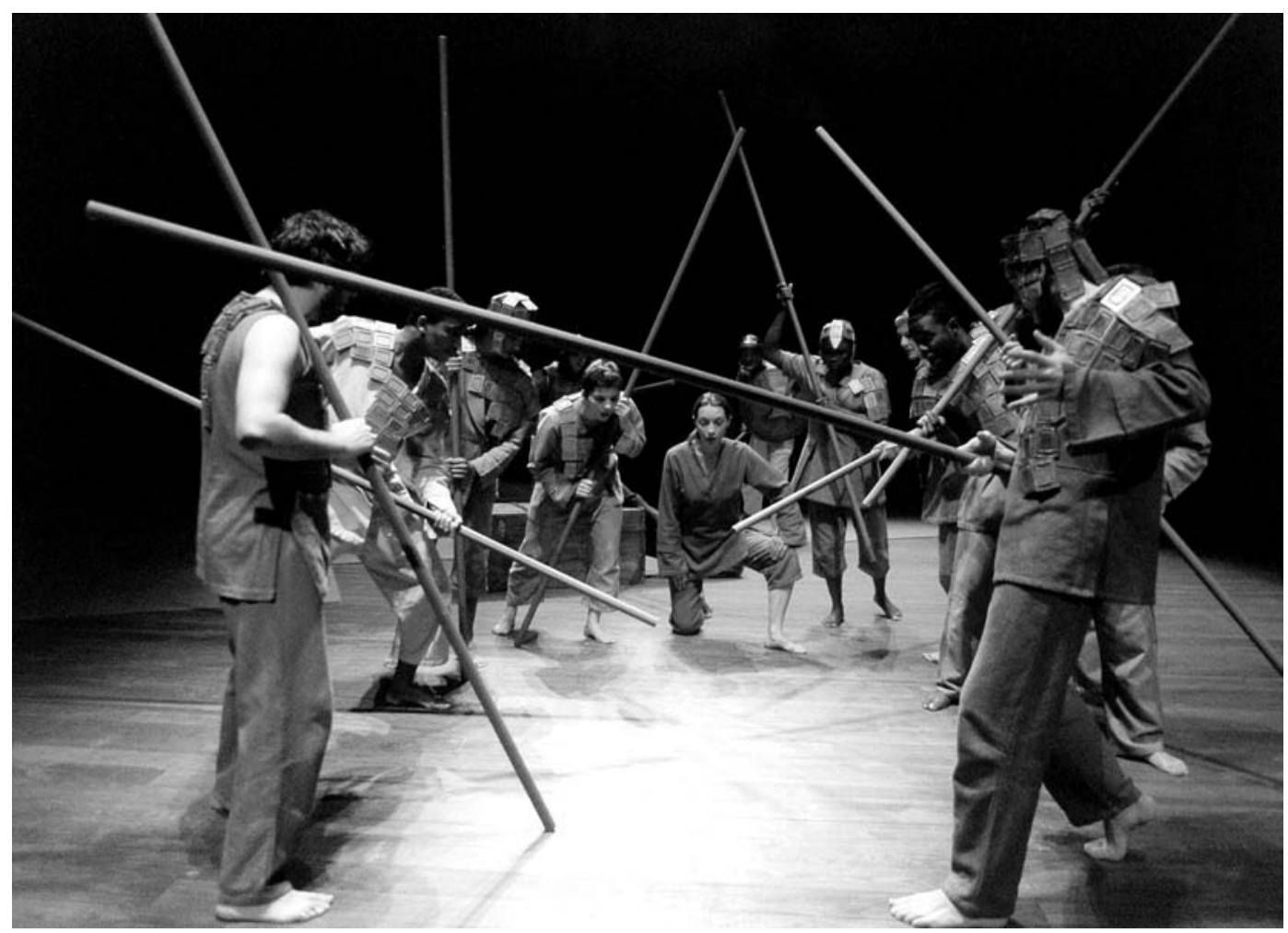

* N.T.: Por razōes que se prendem a uma melhor legibilidade em português, o termo performance, que na nossa lingua se traduz de diversas maneiras - como espectáculo, representação, desempenho, etc. - mas que vem sendo também usado sem tradução, foi neste texto modalizado no sentido de se adequar à vasta gama de sentidos que tem no nosso idioma, mantendose como estrangeirismo nos momentos em que se torna conceito operatório nos contextos antropológicos, sociológicos e estéticos em que a autora o utiliza como tal. Nesta última situação, para não sobrecarregar o texto inutilmente, procedeu-se por vezes ao uso de um pronome que evitasse a sua repetição na mesma frase

Nos últimos anos alterou-se consideravelmente a nossa compreensão dos processos culturais, e portanto também o nosso conceito de cultura. Já não partimos da ideia de que a cultura tem de ser entendida como um texto feito de sinais, que tem de ser lido, como pressupunha o conceito de cultura dominante a partir da viragem linguística dos anos 70: "A cultura como texto". Pelo contrário, viemos a perceber que a cultura é também, se é que não é primeiro que tudo, performance. Não é possivel ignorar até que ponto a cultura é produzida como, e em, performance não só nas "representações" proporcionadas pelas diferentes artes, mas também e antes de tudo nas "representações" associadas a rituais, festivais, comícios políticos, competições desportivas, mostras de moda e coisas do género -, performances estas que, de uma forma mediatizada, chegam a milhões de pessoas. Donde se percebe que o conceito e a teoria da performance estão no centro e no coração de todos os debates no âmbito dos estudos da cultura, da sociedade e da arte.

Assim, proponho-me descrever em traços gerais o conceito de performance que tenho vindo a desenvolver no quadro do centro de investigação "Kulturen des Performativen" (A cultura como performance)'. Apresentoo e explico-o seguindo quatro argumentos:

1. Uma performance ocorre pela co-presença física de actores e espectadores, pelo seu encontro e interacção.

2. 0 que nela acontece é transitório e efémero. Apesar de tudo, o que quer que ocorra durante a sua realização, manifesta-se como hic et nunc, e é experienciado como presente de uma forma particularmente intensa.

3. Uma performance não transmite significados predeterminados. Pelo contrário, é ela que suscita os significados que surgem durante a sua realização.

4. As performances caracterizam-se pela sua qualidade
Cf. o meu livro Ästhetik desPerformativen, Frankfurt a.M., Suhrkamp, 2004 
de "acontecimento"'. 0 modo específico de experiência que permitem é uma forma particular de experiência liminar.

\section{Primeiro argumento:}

Uma performance ocorre na - e através da - co-presença fisica de actores e espectadores. Para que ocorra, dois grupos de pessoas, que agem como "fazedores" e "observadores", têm de se juntar num determinado tempo e num determinado lugar de modo a partilharem uma situação, um lapso de tempo. Uma performance surge desse encontro - a partir da sua interacção.

Isto quer dizer que, num espectáculo, as condições da mediação são completamente diferentes das que subjazem à produção e recepção de textos ou artefactos. Enquanto os actores fazem alguma coisa - se movimentam pelo espaço, manipulam objectos, falam e cantam -, os que agem como espectadores observam-nos e reagem. Pode muito bem acontecer que essas reacções sejam interiores, de ordem imaginativa e cognitiva, ou seja, processos puramente mentais. Todavia, a maior parte das reacções e respostas pode ser observada pelos actores e por outros espectadores - como dar risadas, rir, gritar bocejar, ressonar, soluçar, chorar, comer, beber, comentar o que se está a passar, levantar-se, sair a correr, bater com a porta e assim por diante. A percepção de reacções como estas, por seu lado, provoca outras reacções perceptiveis. 0 que quer que os actores façam tem efeito nos espectadores; o que quer que os espectadores façam tem efeito nos actores e nos outros espectadores. Como conclusão deste estado de coisas, pode argumentar-se que um espectáculo ocorre apenas quando está a acontecer. Existe pela interacção entre actores e espectadores. Daí decorre o facto de o seu decurso não ser completamente planeado nem previsto. Deve ser olhado como um processo autopoiético que se caracteriza por um elevado grau de contingência. 0 que quer que apareça no decurso de um espectáculo não pode ser totalmente previsto no seu início. Muitos elementos emergem no seu decurso como uma consequência de determinadas interacções.

É verdade que os actores determinam as pré-condições decisivas para o decurso de um espectáculo, pré-condições essas que são fixadas pelo processo de encenação. Todavia, não são capazes de controlar em absoluto o seu decurso. Ao fim e ao cabo, é a totalidade dos participantes que dá origem ao espectáculo. Isto não apenas minimiza, mas de facto exclui a possibilidade de uma pessoa individual ou um grupo de pessoas serem capazes de planear completamente o seu decurso, dirigi-lo ou controlá-lo. 0 espectáculo não pode ser controlado por nenhum individuo.

Por outras palavras: o espectáculo abre, assim, a todos os participantes, a possibilidade de, no seu decurso, se descobrirem como um sujeito que pode co-determinar as acções e o comportamento dos outros, e cujas acções e comportamento são, de igual modo, determinados pelos outros. 0 participante individual - seja actor ou espectador
- reconhece-se como um sujeito que não é nem completamente autónomo, nem completamente determinado por outros, como um sujeito que assume a responsabilidade por uma situação que não criou, mas na qual participa.

Isto torna claro que uma qualquer performance mesmo artística - deve também ser encarada como um processo social. Nele, diferentes grupos encontram-se, negoceiam e regulam a sua relação de modos diferentes. Um tal processo social torna-se político no preciso instante em que, durante a sua realização, se desencadeia uma luta pelo poder entre actores e espectadores, na medida em que um grupo tenta impor ao outro determinadas definições da situação ou formas de relação baseadas em ideias, valores, convicções e modos de comportamento. Uma vez que cada participante individual - mesmo se num grau diferente - co-determina o decurso da performance, ao mesmo tempo que se deixa determinar por ele, não há ninguém que nele possa participar "passivamente". Neste sentido, todos os participantes têm a responsabilidade conjunta pelo que nele acontece. De resto, no seu decurso, pode ocorrer algum tipo de agrupamento entre os espectadores. É mesmo possivel que durante a sua realização ou, pelo menos, durante alguns momentos, possa formar-se uma comunidade entre os espectadores ou entre actores e espectadores. É isto que pode fazer com que uma performance se torne num processo eminentemente político - mesmo sem que seja utilizado qualquer tipo de tópico político.

\section{Segundo argumento}

A materialidade de uma performance - as suas dimensões de espacialidade, fisicalidade e qualidade de som - existe no e pelo seu próprio transcurso. Daqui deriva o paradoxo da performance: ela é efémera e transitória, mas o que surge e toma forma no seu decurso, manifesta-se como hic et nunc e é experienciado como presente de uma forma particularmente intensa.

Mesmo se, neste sentido, os espectáculos se esgotem no seu presente, ou seja, na condição de se formarem e desaparecerem, isso não impede que, no seu decurso, sejam usados objectos materiais - objectos que, no final, ficam como seus vestígios e podem ser conservados como tal. Enquanto que numa futura exposição num museu de teatro, etnológico ou de qualquer outro tipo - o interesse se focaliza no próprio objecto, no espectáculo, a atenção é dirigida para o seu uso: que acções são realizadas pela manipulação do objecto e que efeito determinam?

0 que quer que apareça num espectáculo, por um lado, procede das intenções, ideias e planos de vários sujeitos. É a produção ou a encenação que definem que elementos devem aparecer em que momento e em que lugar do espaço, como são movimentados pelo espaço e quando e onde devem desaparecer. Por outro lado, o que quer que surja decorre das interacções descritas acima. Não importa se fenómenos como as respostas perceptíveis 


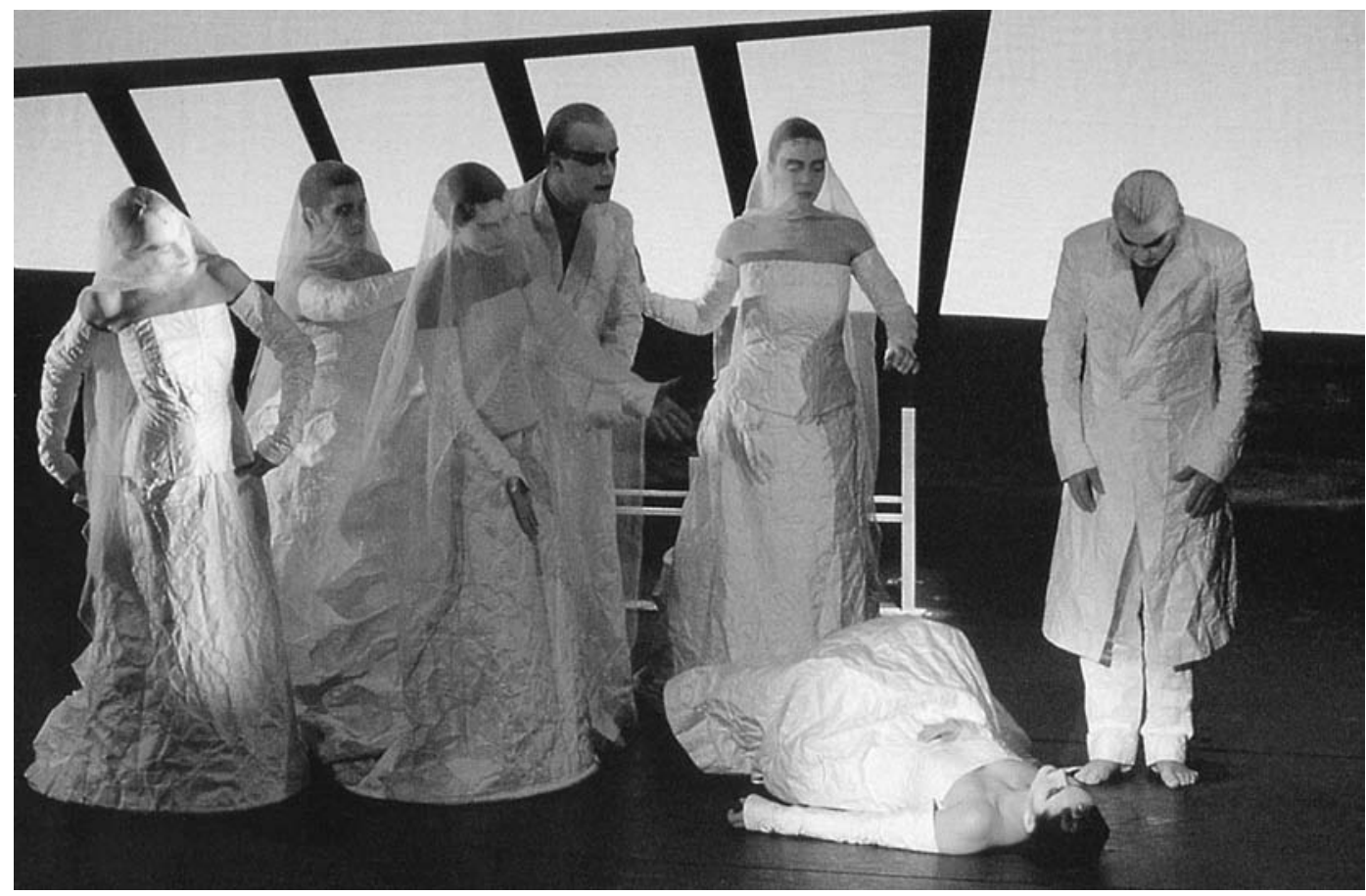

são declaradas constitutivas do espectáculo, como o fez John Cage nas suas "peças silenciosas", que incluiam todos os sons trazidos pelos espectadores, bem como os que entravam no espaço em que decorria o espectáculo vindos de fora; ou se esses elementos são percebidos como perturbadores, considerando-se que a materialidade do espectáculo é definida somente como sendo o que surge intencionalmente trazido pelos artistas envolvidos - a verdade é que o que quer que surja no decurso do espectáculo constitui a materialidade específica desse mesmo espectáculo. É por essa razão que devemos distinguir claramente entre o conceito de encenação e o de espectáculo. Enquanto encenação significa a materialidade do espectáculo que decorre de acordo com os planos e intenções dos artistas, o "espectáculo" inclui todas as formas de materialidade que surgem no seu decurso. É por isso que a encenação é reprodutivel, enquanto o espectáculo só acontece uma vez.

Mesmo que determinados géneros de espectáculo possam ocorrer em espaços que foram especificamente construidos para esse fim, a espacialidade do espectáculo é sempre efémera e transitória. Porque não pode ser identificada com o espaço físico e geométrico em que ocorre. Forma-se no - e através do - espaço da representação. É o espaço da representação que abre possibilidades particulares para a relação entre actores e espectadores, para o movimento e a percepção, que, de resto, organiza e estrutura. Decorre da forma como essas possibilidades são usadas, realizadas, evitadas ou contrariadas, o efeito que terão no espaço do espectáculo. Cada movimento de pessoas, animais, objectos e luz, cada som que ressoe no espaço altera-o, criando, assim, uma nova e diferente espacialidade. 0 espaço do espectáculo não é estável, antes varia e se altera permanentemente. É por isso que num espectáculo, a espacialidade não existe, antes acontece.

Isto é ainda mais verdade quando consideramos a atmosfera particular que co-constitui o espaço do espectáculo. Como mostrou o filósofo Gernot Böhme
(1995), as atmosferas, embora não ligadas a um espaço particular, derramam-se sobre o espaço. Não estão ligadas aos objectos - nem às pessoas - de que ou de quem emanam, nem às pessoas que entram no espaço e têm dele uma percepção física. Geralmente são a primeira coisa que agarra o espectador/visitante, que o marca e que lhe permite assim ter uma experiência especifica do espaço. Uma tal experiência não pode ser explicada com recurso aos elementos singulares do espaço - a sua extensão, os objectos, os cheiros, os sons particulares, ou qualquer outra coisa. Porque não são eles enquanto elementos individuais que criam a atmosfera, mas antes a interacção entre todos eles, que é, regra geral,

cuidadosamente calculada nas produções teatrais. Böhme define atmosferas como "espaços quando marcados pela presença de objectos, seres humanos ou constelações de ambientes. São elas próprias esferas de presença de alguma coisa, da sua realidade no espaço" (1995: 33). A expressão "esferas de presença" reporta-se a um modo particular de os objectos estarem presentes. Böhme explica-o como "êxtase do objecto", como o modo pelo qual uma coisa aparece de forma própria como presente. Não são apenas as cores, os cheiros ou os sons que são conceptualizados como êxtases - ou seja, as chamadas qualidades secundárias da coisa -, mas antes as suas qualidades primárias, como a extensão e a forma. 0 êxtase da coisa resulta do facto de as coisas terem um efeito sobre 0 ambiente, que atrai - requer mesmo - a atenção, e de elas surgirem aos que as percepcionam de uma forma particularmente intensa como presentes. Impõem-se à nossa atenção.

A atmosfera contribui consideravelmente para a produção da espacialidade. É por causa da - e através da - atmosfera, que parece emanar do espaço e das coisas - incluindo os cheiros que exalam e os sons que produzem -, que as coisas e o espaço aparecem ao sujeito, que nele entra, como presentes num sentido mesmo enfático. Não só se apresentam nas suas qualidades ditas primárias e secundárias, como, além disso, na atmosfera, eles invadem 
setenta e seis

Sinais de cena 4. 2005

Estudos aplicados

Erika Fischer-Lichte

A cultura como performance: Desenvolver um conceito
200\% and Bloody Thirsty,

criação da Forced

Entertainment, ICA,

Londres, 1987,

fot. Hugo Glendinning.

A tomada do Palácio de

Inverno

enc. Nicolas Evreinov,

1920

de John Cage,

Toronto, 1968

(Teeny Duchamp

Marcel Duchamp

e John Cage a jogar

xadrez num tabuleiro

"preparado"),

fot. Shigeko Kubuta.

A propósito deste conceito, v. Erika Fischer-

Lichte, "Embodiment -

From Page to Stage: The Dramatic Figure", Assaph, Studies in Theatre n. ${ }^{16}$, 2000, pp. $65-75$ o corpo do sujeito que percepciona, para serem experienciados como luz, cheiros e sons. Porque o espectador não se defronta com a atmosfera, não se distancia dela, antes é rodeado por ela, mergulha nela.

Por causa da co-presença física de actores e espectadores, a fisicalidade tem um papel essencial nos espectáculos. Num espectáculo lidamos com o corpo enquanto "presença", assim como enquanto corpo semiótico. Os actores aparecem com o seu ser-no-mundo físico, não importa se é um actor de teatro, um político, um atleta, um xamã, um padre, um cantor, um bailarino ou a simples pessoa com quem se interage no quotidiano normal. Do seu corpo físico pode emanar uma radiação particular que os outros participantes/espectadores sentem fisicamente. Em muitos casos, é como se uma corrente de energia emanasse deles, e se transferisse para os espectadores, conferindo-Ihes, por sua vez, essa energia. De uma forma especial e particularmente intensa, o actor é experienciado como "presente". Ao mesmo tempo, o espectador, que é atingido por essa corrente, experienciase de uma forma especial e particularmente intensa como presente.

0 corpo físico do actor e do espectador é a base existencial de todo o tipo de espectáculo - seja na vida quotidiana, nas artes ou numa performance cultural. 0 que quer dizer que o carácter performativo da cultura não pode ser, em boa verdade, investigado sem recurso à fisicalidade de todos os que participam num espectáculo. Não são as ideias, os conceitos nem os sentidos que devem ser examinados em primeiro lugar, para dar visibilidade ao carácter performativo da cultura, mas sim os corpos físicos particulares através dos quais e entre os quais se produz o espectáculo - o corpo do actor que, ao aplicar algumas técnicas e práticas, consegue ocupar o espaço e chamar toda a atenção dos espectadores sobre si, a sua presença física, assim como o corpo dos espectadores, que respondem de forma particular a uma experiência de presença como esta.

Nas performances, é o corpo físico dos participantes, o corpo nos seus diferentes estados - psicológicos, afectivos, energéticos e motores - que opera sobre o corpo físico dos outros e é capaz de evocar neles particulares estados psicológicos, afectivos, energéticos e motores. Em todos estes casos, o corpo físico aparece muitas vezes ao mesmo tempo que o corpo semiótico. Seja numa interacção quotidiana, num ritual, ou num espectáculo de teatro aquele que faz o papel de espectador não só sente o outro enquanto fisicalidade presente, como também levanta a questão sobre o que significa o outro baixar as pálpebras, erguer o braço ou movimentar-se pelo espaço - em qualquer caso, se esses movimentos querem dizer alguma coisa.

Enquanto até agora o corpo semiótico nos espectáculos tem atraído e recebido muita atenção, o corpo físico dos actores e espectadores só raras vezes se tornou visível. Isto é tanto mais surpreendente quanto o corpo físico e
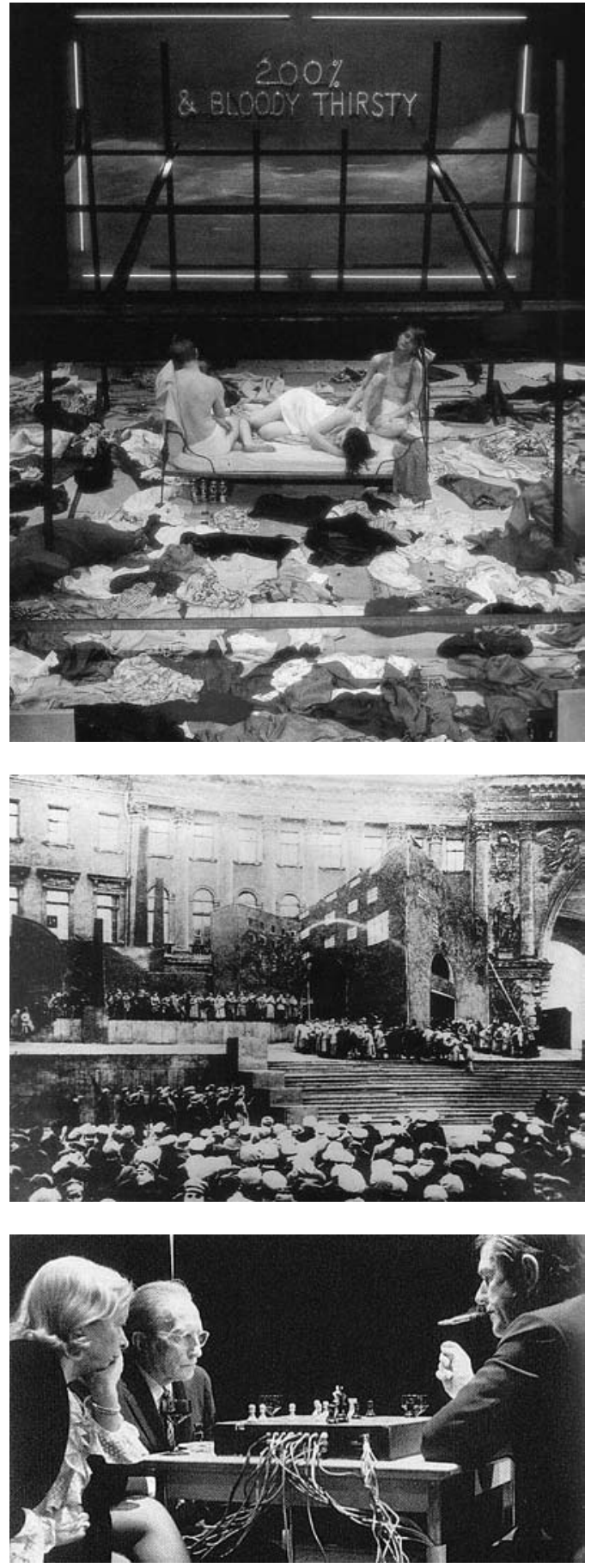

o corpo semiótico estão indissoluvelmente ligados um ao outro - o que permite pensar no corpo físico sem referência ao semiótico, embora o contrário não se verifique. Parece bastante produtivo relacionar ambos através do conceito de "corporização". Por corporização não quero dizer processo de emprestar corpo temporariamente a algo mental - uma ideia, um conceito, um sentido ou mesmo um espírito incorpóreo - que precisa de um corpo para falar e ganhar uma aparência. 0 termo corporização referese antes aos processos físicos pelos quais o corpo físico se produz a si próprio, em cada caso, enquanto corpo físico e ao mesmo tempo com significados específicos. Assim, o actor, por processos de corporização, produz o seu corpo físico de um modo muito específico, que por vezes é experienciado como "presença" e, ao mesmo tempo, 

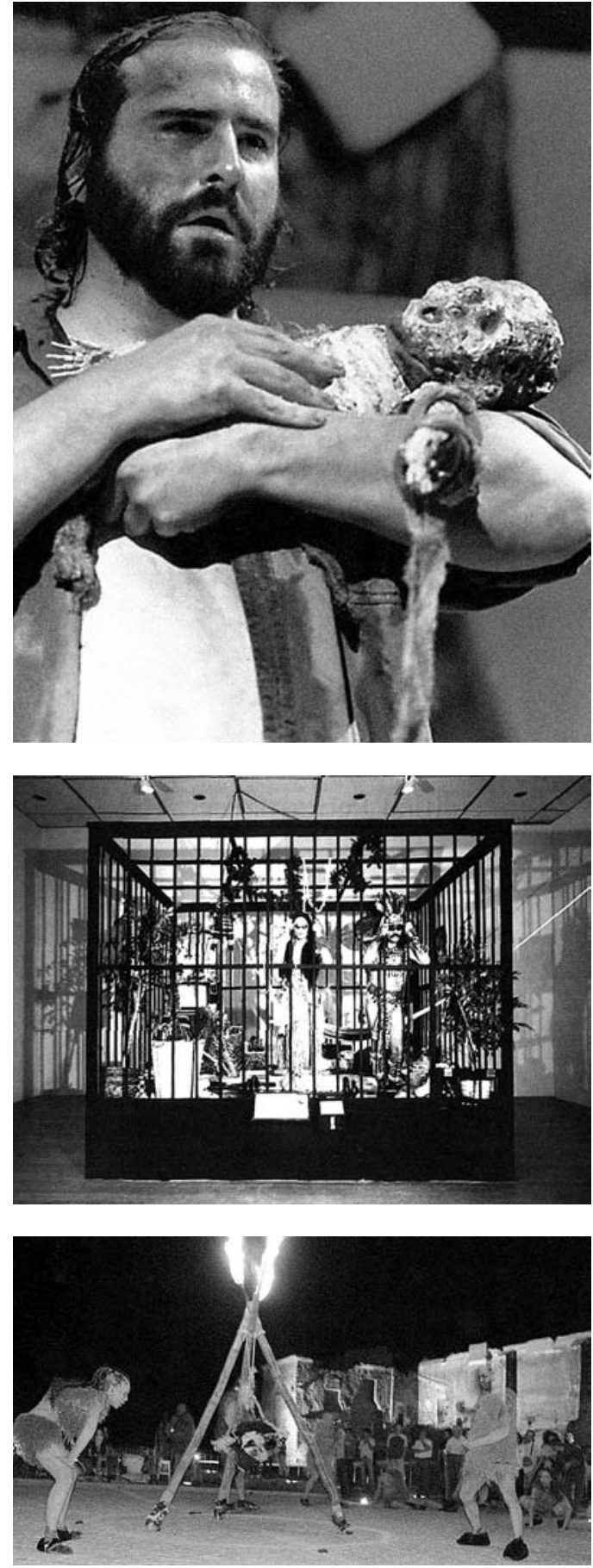

produz uma figura dramática, por exemplo, Hamlet. A "presença", bem como a figura dramática não existem para lá dos processos particulares de corporização pelos quais o actor os faz existir no espectáculo; pelo contrário, são por eles produzidas.

0 que é característico do trabalho do actor pode ser aplicado a todo o tipo de performers e a todas as acções noutro género de performances. Mesmo aqui, os que actuam produzem o seu corpo fisico de um modo particular e assim, ao mesmo tempo, os significados específicos sejam eles de uma figura dramática ou de outro tipo qualquer de identidade, de um "papel" social ou de uma ordem simbólica. Todos estes tipos de significados radicam num corpo físico, não existem ao lado ou para lá dele. Aquilo a que chamamos "presença" num actor, num xamã ou num padre também pode ser chamado carisma. Mas isso abre toda uma outra discussão.

\section{Terceiro argumento}

Uma performance não transmite significados predeterminados. Pelo contrário, é a performance que produz os significados que surgem no seu decurso.

Durante muito tempo, os académicos partiam do pressuposto de que os espectáculos serviam a intenção de comunicar significados predeterminados específicos. A premissa era de que a representação de um texto dramático transmite os sentidos nele fixados ou uma sua interpretação; que numa festa de corte do século XVII se realizava um particular programa alegórico predeterminado, ou que festas políticas ou outros espectáculos de massas devem ser vistos como a representação de um poder individual como o de Alexandre Magno, Augusto, Luís XIV, Napoleão, Mussolini, Estaline ou Hitler.

No caso de serem consistentes os dois primeiros argumentos, uma opinião como esta já não pode ser aceite. Porque, por um lado, há os elementos imprevistos e não planeados que se produzem na interacção entre actores e espectadores durante o espectáculo que irão perturbar o programa predeterminado. E, por outro lado, ao focalizar a atenção na presença particular dos corpos físicos, êxtases de coisas e atmosferas, ela distrair-se-á dos corpos, objectos e espaços, etc. semióticos, e assim vai contra o procedimento de uma tal interpretação. Pelo contrário, é o espectáculo que produz significados. Neste sentido, os significados que são produzidos no - e durante o - espectáculo devem ser encarados como emergentes.

Percepcionar o corpo, as coisas e o espaço na sua presença específica não significa percepcioná-los como desprovidos de significado. É dizer antes percepcionar todos estes fenómenos como alguma coisa. Não estamos aqui a lidar com um estímulo não específico, com meros dados dos nossos sentidos, mas sim com a percepção de alguma coisa "como" alguma coisa. Na minha percepção, as coisas aparecem na sua particular fisicalidade. Significam aquilo que aparentam. A sua auto-referencialidade não deve ser, por isso mesmo, descrita como uma mediação entre um sentido predeterminado nem como uma dessemantisação, mas sim como um processo de um tipo muito particular de produção de sentido. Este processo é realizado como a percepção de um fenómeno na sua materialidade particular, no seu ser físico. Percepcionar e gerar sentido são, aqui, executados no - e pelo - mesmo acto. 0 significado é produzido pelo - e no - acto de percepcionar. Por outras palavras: não há uma coisa que primeiro percepcionamos e à qual - no acto da interpretação - atribuímos o significado de qualquer outra coisa. Pelo contrário, percepcionar uma coisa como coisa efectivase ao mesmo tempo como um processo de produção do seu significado enquanto ser físico particular que é.

A este modo de percepção alia-se um outro muito diferente. Primeiro, o elemento que surge é percepcionado
Buried Child,

de Sam Shepard, enc. Meg Patterson, Warehouse Repertory Theatre, 1999 (Tom Lenocci), fot. Garth Hagerman. de Coco Fusco e Guillermo Gomez-Peña, Madrid 1992.

Pre-Historic'Ball, pelo Teatro Lua Cheia, no âmbito do projecto Arte em Campo, 2004 fot. Lena. 
no - e como o - seu ser físico. No momento em que a atenção deixa de se focalizar no elemento, percepcionado enquanto tal, e começa a desviar-se, o elemento aparece como um tipo de significante ao qual se podem referir as mais diversas associações como sendo os seus significados, como imagens, ideias, memórias, emoções, pensamentos, etc. É muito discutível se tais associações surgem de acordo com regras particulares e, portanto, de forma previsivel. Assume-se antes que derivam do sujeito que percepciona, mais ou menos por acaso, mesmo que possam ser explicadas a posteriori. Parecem não estar às ordens de quem percepciona. Emergem simplesmente no acto.

Uma tal oscilação na percepção - entre focalizar o fenómeno como auto-referencial e pelas associações que pode desencadear -, designo como a ordem da presença. Distingo-a de um outro tipo de percepção e produção de sentido que é a ordem da representação. Percepcionar o corpo do actor no seu ser-no-mundo físico lança as bases da ordem da presença. Percepcioná-lo como um signo de uma figura dramática ou outra ordem simbólica estabelece a ordem da representação. Esta exige relacionar qualquer elemento percepcionado, respectivamente, com a figura dramática ou com a ordem simbólica. Enquanto a primeira ordem produz sentido enquanto ser físico do que é percepcionado - o que não exclui que esse sentido possa evocar outros sentidos que não estão directamente ligados aos fenómenos percepcionados como uma cadeia de associações -, a segunda ordem produz sentidos que, no cômputo final, constituem a figura dramática ou outra ordem simbólica.

Durante um espectáculo, a nossa percepção oscila entre ambas as ordens de percepção. No momento em que passa de uma para a outra, surge a ruptura, ocorre uma descontinuidade. Produz-se um estado de instabilidade, que coloca o sujeito que percepciona entre duas ordens, que o transfere para um estado intermédio, um estado de liminaridade. Cada mudança, cada instabilidade faz com que a dinâmica do processo de percepção tome um outro rumo. Quanto mais frequente é a mudança, mais vezes o sujeito que percepciona começa a vaguear entre os dois mundos, entre as duas ordens de percepção. Cada vez mais toma consciência da sua inabilidade para causar, dirigir e controlar as mudanças. Pode tentar deliberadamente ajustar a sua percepção à mudança - para a ordem da presença ou para a ordem

${ }^{4}$ Para o conceito de intermédio e de liminaridade vejam-se Arnold van Gennep, The Rites of Passage, Chicago Chicago Univ. Press, 1960

(1.a ed. 1909) e Victor Turner, The Ritual Process:

Structure and Anti-

Structure, Chicago, Aldine, 1969. da representação. Em breve, contudo, terá consciência de que a mudança ocorre mesmo que o não queira, que acontece, que the acontece, que passa para um estado entre as duas ordens sem querer ou sem ser capaz de o evitar. Num momento como esse, o espectador experiencia a sua própria percepção como emergente, fora da sua vontade e do seu controlo, mas também, como realizada conscientemente.

Isto quer dizer que a mudança chama a atenção do sujeito que percepciona para o processo da percepção, bem como para a sua dinâmica particular. No momento da mudança, o processo da percepção torna-se, assim, visível, consciente, e objecto de percepção ele próprio. 0 sujeito que percepciona começa a reconhecer-se como sujeito que percepciona, que produz novos sentidos, que, por sua vez, geram outros sentidos e por ai fora. Desta maneira, o processo de percepção está continuamente a mudar. 0 que será percepcionado e que sentidos podem ser produzidos parece uma coisa cada vez menos previsivel. 0 sujeito que percepciona torna-se consciente de que os sentidos não lhe são dados, mas que é ele que os produz e que ele poderia ter gerado sentidos completamente diferentes, se a mudança de uma ordem para a outra tivesse ocorrido mais cedo ou mais tarde, ou fosse mais ou menos frequente.

\section{Quarto argumento}

Os espectáculos caracterizam-se pelo seu carácter de acontecimento. 0 modo específico de experiência que permitem é uma forma particular de experiência liminar.

De forma a entender de forma adequada os espectáculos, eles não devem ser tidos como obras de arte, mas como acontecimentos. Uma vez que um espectáculo se produz pela interacção entre actores e espectadores, uma vez que ocorre no - e através do - processo autopoiético, é impossivel etiquetá-lo com sendo obra. Porque quando o processo poiético chega ao fim, o espectáculo não é dado como sendo o seu resultado, antes acontece que o espectáculo acabou. Passou, e está definitivamente perdido. Existe apenas como - e no - processo de apresentação, existe apenas como um acontecimento.

0 espectáculo como acontecimento - bem diferente da encenação - não é recorrente e não pode ser repetido. É impossivel que ocorra uma vez mais exactamente a mesma constelação entre actores e espectadores. As reacções dos espectadores e o seu efeito sobre os actores e outros espectadores serão diferentes em cada um dos espectáculos. Um espectáculo deve ser entendido como um acontecimento também no sentido em que nenhum participante terá sobre ele um controlo completo, que é antes algo que the acontece, e em especial aos espectadores. Isto é verdade não só relativamente às consequências da co-presença física de actores e espectadores, mas também em relação ao carácter particular de presença em que ocorrem os fenómenos, bem como à emergência de sentidos. Como se explicou atrás relativamente à mudança da percepção, também ocorre com o sujeito que percepciona transferindo-o para um estado intermédio, para um estado de instabilidade.

0 carácter particular de acontecimento dos espectáculos caracteriza-se ainda por um estranho colapso de oposições. Os participantes num espectáculo experienciam-se a si próprios como co-determinando o seu decurso e, ao mesmo tempo, como sendo determinados por ele. Vivem através do espectáculo um processo estético, bem como social, e mesmo político, no decurso do qual são negociadas relações, são travadas lutas pelo poder, são construidas e dissolvidas 


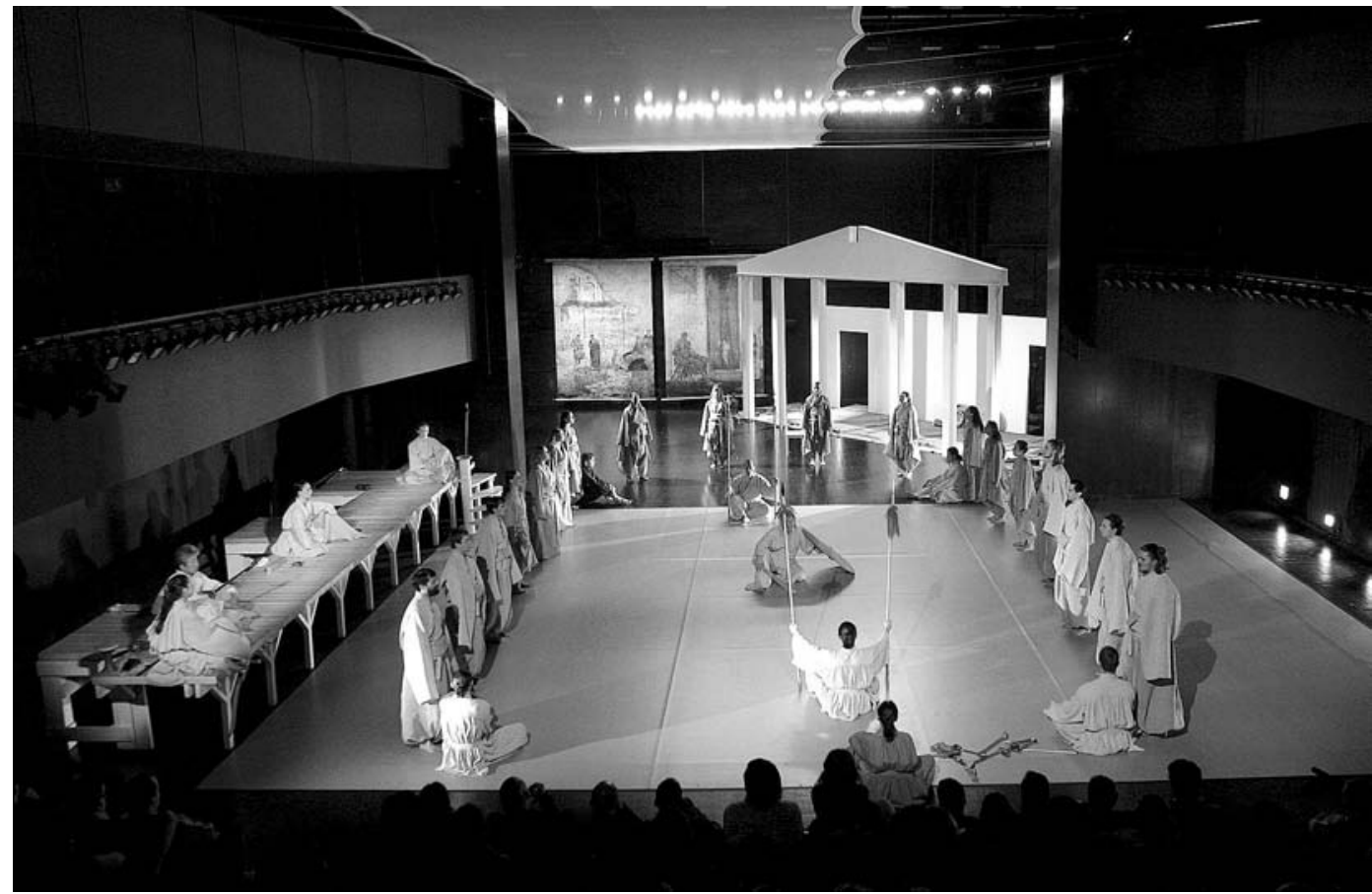

comunidades. A sua percepção segue tanto a ordem da presença como a da representação. Quer dizer: o que nas culturas ocidentais é tradicionalmente considerado uma oposição a ser compreendida por pares de conceitos dicotómicos - como sujeito autónomo vs sujeito determinado por outros; arte vs realidade/politica; presença vs representação - é experienciado nos espectáculos não no modo de "ou-ou", mas no de "e também". A oposição cai, as dicotomias parecem dissolver-se.

No momento em que isto ocorre, no momento em que um pode ser o outro, a nossa atenção é atraída pela passagem de um estado ao outro, pela instabilidade que, por sua vez, é experienciada como um acontecimento. Abre-se no espaço entre os opostos um intervalo. 0 "intermédio" torna-se, assim, uma categoria privilegiada: aponta para o limiar entre os espaços, para o estado de liminaridade, para o qual o espectáculo transfere todos os que nele participam.

Uma vez que esses pares de conceitos dicotómicos não servem apenas como ferramentas para a descrição e cognição do mundo, mas também como reguladores para as nossas acções e comportamentos, a sua desestabilização redunda não só numa desestabilização da nossa percepção do mundo, de nós próprios e dos outros, mas também na quebra das regras e normas que guiam o nosso comportamento. Dos pares de conceitos podem ser deduzidas molduras diferentes como "Isto é teatro/arte" ou "Isto é uma situação social ou política". Tais molduras implicam premissas para um comportamento adequado à situação que integram. Ao admitir a colisão de molduras opostas ou apenas diferentes, ao permitir, assim, que valores ou exigências diferentes, parcial ou mesmo totalmente opostos, sejam colocados lado a lado, de modo a entre si se validarem ou anularem, os espectáculos criam situações liminares. Transferem o espectador por entre todas essas regras, normas e ordens, transferem-nos para dentro de uma crise.

Isto quer dizer que o espectáculo transfere o espectador para um estado que o aliena da vida quotidiana, das normas e regras que nela são válidas, sem, todavia, Ihe mostrar como pode encontrar uma reorientação. Um tal estado é percepcionado como um prazer, bem como um tormento. A transformação que se opera no sujeito pode ser muito diversa: na maior parte dos casos serão transformações temporárias, que duram apenas um tempo limitado, o tempo do espectáculo. Elas incluem mudanças dos estados - fisiológicos, afectivos, energéticos e motores - do corpo, mas também efectivas mudanças de estatuto, como de um estatuto de espectador para o de actor, ou na construção de uma comunidade entre actores e espectadores ou apenas entre espectadores. Essas mudanças ocorrem durante o espectáculo e são perceptiveis; todavia, quando o espectáculo acaba, geralmente não se prolongam. Pode apenas discutir-se e decidir-se relativamente a casos individuais se a experiência da desestabilização da percepção da realidade, de si próprio e dos outros, a perda de normas e regras válidas leva de facto a uma reorientação do indivíduo em causa e, nesse sentido, a uma transformação contínua e de longa duração. Pode até acontecer que, depois de deixar o espaço do espectáculo, o espectador considere a sua desestabilização temporária como sem sentido e sem razão e tente regressar à sua anterior percepção da realidade, de si próprio e dos outros, ou que, mesmo depois do fim do espectáculo, permaneça durante um bom bocado de tempo num estado de desorientação e muito mais tarde, através de reflexões, chegue a uma reorientação ou regresse aos seus antigos valores e padrões de comportamento. Seja qual for o caso, ele passou por uma experiência liminar enquanto participava no espectáculo.

No caso de espectáculos artísticos chamamos a uma tal experiência liminar uma experiência estética; no caso de rituais, uma experiência ritualista. A experiência para que abrem as performances da mais variada espécie é geralmente uma experiência liminar. Todavia, podemos distinguir a experiência liminar como uma experiência estética ou como uma experiência ritualista. A experiência 
ritualista caracteriza-se por dois critérios que não são válidos para a experiência estética: a irreversibilidade e a aceitação social. Contudo, embora a experiência estética não resulte numa mudança de estatuto ou de identidade socialmente aceite, pode provocar em participantes individuais uma mudança da sua percepção da realidade, de si próprios e dos outros. Isto é verdade não só para os artistas envolvidos, mas também para os espectadores. Neste sentido, o acontecimento que é o espectáculo pode resultar numa transformação dos participantes que é capaz de durar para lá do fim do próprio espectáculo.

\section{Conclusões}

0 conceito de performance, tal como foi descrito acima, implica um enorme potencial inovador para os estudos culturais, sociais e artísticos, que quero, por fim, indicar em breves palavras.

Nos estudos artísticos, o conceito de obra de arte é central. A obra tem de ser analisada, no que diz respeito aos diferentes mecanismos artísticos usados, e ser interpretada de modo a podermos compreendê-la. Se as artes já não produzem obras, mas sim performances, ou seja, acontecimentos, como ocorre não só no teatro, na música e na arte performativa, mas também, desde os anos 60 do séc. XX, cada vez mais em todas as artes, então não pode ser aplicada nem uma estética da obra, nem a estética da produção e recepção que se Ihe referem. Do que se trata agora é do desafio para desenvolver novas estéticas, acima de tudo teorias da experiência estética, assim como, em lugar da análise da obra, novos métodos de análise da performance.

As disciplinas hermenêutico-históricas, quando lidam com os espectáculos, já não poderão partir da premissa de que eles estão a realizar um particular programa alegórico ou a representar o poder de um indivíduo, ou que a representação de um texto dramático pode ser vista como a sua interpretação. Pelo contrário, as abordagens hermenêutico-históricas têm de ter em conta que os significados emergem não antes do processo do espectáculo, mas no seu decurso, não podendo, portanto, confundir-se com os significados que grupos de pessoas ou indivíduos quiseram exprimir com o espectáculo.

0 conceito de espectáculo acaba por ser também de grande importância para as ciências sociais. Porque, partindo da premissa de que num espectáculo todos os participantes, ou seja, actores e espectadores, estão igualmente envolvidos na medida em que o co-determinam e se deixam determinar por ele, a tese corrente e popular da manipulação cai por terra. Dizer que festas políticas e outros espectáculos de massas servem bem a finalidade de manipular a população que neles participa de acordo com as intenções os planos do governante ou das classes dominantes pressuporia que os organizadores seriam capazes de aplicar estratégias de encenação com o poder de dominar o público passivo, exactamente de forma précalculada, levando-o a adoptar o comportamento desejado. Se nos lembrarmos da interacção entre actores e espectadores, bem como da co-responsabilidade que cada participante tem pelo decurso do espectáculo, parece pouco provável que possa ocorrer de facto uma tal manipulação.

Os espectáculos transmitidos pelos media levantam uma questão especial. Gravações de espectáculos em filme, pela televisão ou em vídeo não podem ser definidos e compreendidos como espectáculos, uma vez que não se verifica a co-presença física de actores e espectadores constitutiva de um espectáculo. Por essa razão, não estão incluídos no conceito da performance, ou sequer no conceito da performatividade. Além disso, há uma diferença considerável entre os espectáculos mediatizados, por um lado, e, por outro, os espectáculos que recorrem ao uso dos diferentes media e de todos os tipos de tecnologia de reprodução. Tais espectáculos são um desafio à nossa percepção por exigirem novos modos de percepção que põem em causa o próprio conceito de espectáculo.

0 potencial inovador, que o conceito da performance implica, tem ainda de ser descoberto e explorado pelos estudos culturais e pelos estudos artísticos.

\section{Referência bibliográfica}

BÖHME, Gernot (1995) Atmosphäre. Essays zur neuen Ästhetik, Frankfurt a.M., Suhrkamp Verlag.

Este artigo é a tradução da conferência proferida a 29 de Abril de 2005 na Faculdade de Letras de Lisboa, no âmbito da acção do Centro de Estudos de Teatro, que, para esta iniciativa, teve o apoio da FACC, da Faculdade de Letras da Universidade de Lisboa e da Fundação Calouste Gulbenkian. 